POLITEJA

nr 1(58), 2019, s. 153-171

https://doi.org/10.12797/Politeja.16.2019.58.09

\author{
Piotr Mirocha \\ Uniwersytet Jagielloński \\ pamirocha@gmail.com
}

\title{
EUROPA I JEJ WYOBRAŻONE GRANICE W MEDIALNYM DYSKURSIE CHORWACKIM PO 2012 ROKU
}

ABSTRACT Europe and Its Imaginary Borders in the Croatian Media Discourse after 2012

Today Croatia is one of the countries situated on the border of the European Union. It joined the EU in 2013, i.a. already after the financial crisis of 2008 and just before the permanent crisis resulting from the indebtedness of the Southern peripheries of the EU, revealing of the humanitarian situation of migrants at the Mediterranean and Balkan borders of the Union, as well as a rise in xenophobia in numerous member states. Therefore, imaginary borders of Europe in the Croatian media discourse after 2012 can be a significant research field. This paper presents preliminary results of an analysis of a large corpus of articles from the Internet issue of a daily newspaper Večernji list from October 2012 until October 2017. The analysis is focused on the linguistic modelling of the notion of Europe (especially in the context of the European integration) and its limits (especially in the context of migration). A brief background concerning the cultural history of the notion of Europe in the Croatian cultural universe is also provided.

Keywords: Croatian media discourse, Europe, crisis, migration, discourse analysis

Słowa kluczowe: chorwacki dyskurs medialny, Europa, kryzys, migracja, analiza dyskursu 


\begin{abstract}
Chorwacja jest obecnie jednym z państw leżących na granicy Unii Europejskiej. Do organizacji wstą̧iła w 2013 r., a więc już po kryzysie finansowym 2008 r., a tuż przed permanentnym kryzysem związanym z zadłużeniem południowych peryferiów UE, humanitarną sytuacją migrantów na śródziemnomorskich i bałkańskich granicach Unii i wzrostem nastrojów ksenofobicznych w wielu państwach członkowskich. Stąd wyobrażone granice Europy w chorwackim dyskursie medialnym po 2012 r. mogą stanowić istotny przedmiot badań.

Niniejszy artykuł koncentruje się na preliminarnych rezultatach badań dużego korpusu artykułów internetowego wydania dziennika „Večernji list” od października 2012 do października 2017 r. Analiza przeprowadzona została pod kątem modelowania pojęcia Europy (zwłaszcza w kontekście integracji z UE) i jej granic (przede wszystkim w kontekście migracji).
\end{abstract}

\title{
HISTORYCZNE ASPEKTY CHORWACKIEGO DYSKURSU O EUROPIE
}

Rozważania na temat dyskursu o Europie - czy też, jak będzie on określany w dalszym ciągu tekstu, dyskursu europejskiego ${ }^{1}-$ w prasie chorwackiej wypada zacząć od przybliżenia kontekstu historycznego. Najogólniej rzecz biorąc, począwszy od pierwszych symptomów nowoczesności - a więc drugiej połowy XVI wieku - aż do kongresu berlińskiego z $1878 \mathrm{r}$. dominował w Chorwacji porządek dyskursu przedmurza ${ }^{2}$. Posiadał on zarówno aspekt europejskiej autoidentyfikacji, jak i aspekt krytyczny wobec Europy. Krytyka ta jednak opierała się na wytykaniu pozostałym państwom niewdzięczności za chorwacki wkład w walkę z Obcym - Turcją osmańską ${ }^{3}$.

Ów porządek dyskursu ostatecznie stracił podstawy polityczne po kongresie berlińskim, kiedy Turcja osmańska utraciła większość posiadłości europejskich. Stąd też w drugiej połowie XIX wieku wyłaniają się konkurujące ze sobą próby definicji granic wspólnoty symbolicznej. Można tu podać przykład wczesnych jugoslawistów. Projektowana, wyobrażona Jugosławia jawiła się im jako pozytywnie wartościowana wspólnota wieloetniczna w ramach wspólnoty europejskiej. Natomiast jako negatywnie wartościowany obszar poza granicami Europy postrzegany był świat islamu - a więc także

Z punktu widzenia dyscypliny analizy dyskursu określenie dyskurs europejski może budzić wątpliwości, zaś wyrażenie dyskurs o Europie dużo jaśniej wskazuje, że Europa stanowi temat czy treść dyskursu. Mimo to, decyduję się na korzystanie z określenia dyskurs europejski z uwagi na jego poręczność. Należy pamiętać, że za każdym razem oznacza ono tyle co dyskurs o Europie.

2 W praktyce analizy dyskursu przy klasyfikacji dyskursów z uwagi na idee w nich przekazywane unika się raczej pojęcia dyskurs z przymiotnikiem i systemy łączące dyskurs z ideami nazywa np. odmianami światopoglądowymi dyskursu, porządkami dyskursu (T. van Dijk, Badania nad dyskursem, [w:] Dyskurs jako struktura i proces, red. T. van Dijk, przeł. G. Grochowski, Warszawa 2001, s. 12), profilami dyskursu czy ideologiami po prostu (M. Lisowska-Magdziarz, Analiza tekstu w dyskursie medialnym, Kraków 2009, s. 17). W niniejszym artykule skłaniał będę się do pojęcia porządku dyskursu.

3 P. Stehlík, Predzide i most: simbolička konceptualizacija graničnoga položaja Hrvatske u izvornome jugoslavizmu, [w:] Symbole wtadzy - wtadza symboli, red. M. Dyras, B. Suchoń-Chmiel, T. Kwoka, Kraków 2014, s. 229-240. 
sąsiednia Bośnia. Widziano ją jako coś, co należałoby cywilizować i dopiero następnie włączyć w obręb „cywilizacji europejskiej”. Ta formacja ideowa bywa nazywana przez niektórych badaczy „orientalizmem pograniczy”.

Należy wspomnieć, że istniały także skrajne nurty myśli społeczno-politycznej (pewne odłamy nacjonalistycznej Partii Prawa), odmawiające narodom bałkańskim - przede wszystkim prawosławnym Serbom - przynależności do „cywilizacji europejskiej”, powołując się na kryteria rasowe ${ }^{5}$. Po rozpadzie wielonarodowych imperiów w 1918 r. powstaje wspólne państwo Serbów, Chorwatów i Słoweńców, a od 1929 r. Królestwo Jugosławii. Wielość konkurujących porządków dyskursu europejskiego w międzywojennej Jugosławii odpowiadała złożoności sytuacji politycznej w tym państwie.

Po 1945 r. Chorwacja funkcjonowała jako republika w ramach socjalistycznej Jugosławii. Zarówno na skutek specyficznego przebiegu walki z faszystowskim najeźdźcą, jak i konfliktu ze Związkiem Radzieckim po 1948 r. tożsamość jugosłowiańska była często rozumiana jako most między zwaśnionymi blokami - kapitalistycznym Zachodem i zdominowanym przez Związek Radziecki Wschodem 6 . Warto zwrócić uwagę, że autoidentyfikacja w roli pomostu stanowiła tożsamość globalną traktowaną jako istotna część oficjalnej (a nierzadko także potocznej) ideologii, np. w ramach Ruchu Państw Niezaangażowanych, łączącym m.in. Jugosławię Josipa Broza Tity, Indie Jawaharlala Nehru, Indonezję Sukarno czy Egipt Gamala Abdela Nasera. Do lat 80. opozycyjne porządki dyskursu w kraju bardzo rzadko kwestionowały tę perspektywę, choć niewątpliwie można mówić o stopniowym wyczerpywaniu się jej - co stwarzało coraz więcej miejsca na partykularne dyskursy nacjonalistyczne.

W 1991 r. rozwiązano ZSRR, rok później podpisany został traktat z Maastricht: zasadniczo zmieniło to orientację geopolityczną państw Europy Środkowoi Południowo-Wschodniej. W 1991 r. Chorwacja ogłosiła niepodległość, a Jugosłowiańska Armia Ludowa zaatakowała nowo powstałe państwo. W atmosferze wojny i nacjonalistycznych rządów dochodziło do coraz powszechniejszej aktualizacji motywów kultury tradycyjnej - które za badaczkami kultur Słowian południowych można określać retradycjonalizowanymi porządkami dyskursu ${ }^{7}$. Na skutek tego do głównych motywów dyskursu chorwackiego lat 90. zaliczyć można porządek dyskursu przedmurza z jego aspektem „eurosceptycznym” z jednej strony, a z drugiej strony - modernizacyjny porządek dyskursu, po reorientacji geopolitycznej 1989 r. symbolizowany przez metaforę "drogi do Europy”; wreszcie istniały także pewne „kontrporządki” $n p$. tzw. jugonostalgiczny.

Tamże.

J. Rapacka, Leksykon tradycji chorwackich, Warszawa 1997, s. 173.

6 M. Czerwiński, Europa jako znak w nowomowie jugostowiańskich komunistów na przyktadzie wystąień Josipa Broza Tity, „Slavia Meridionalis” 2012, nr 12, s. 249-264.

Zob. M. Dąbrowska-Partyka, Geografia wyobrażona. Mapy jugostowiańskie i postjugostowiańskie, [w:] Zrozumieć Stowiańszczyznę, red. M. Dąbrowska-Partyka, Kraków 2010, s. 34-35; M. Dyras, Re-inkarnacje narodu. Chorwackie narracje tożsamościowe w latach dziewięćdziesiątych XX wieku, Kraków 2009, s. 14-24. 
Zawarty w 1995 r. traktat z Dayton zakończył wojny na terenie Chorwacji oraz Bośni i Hercegowiny ${ }^{8}$. W 1999 r. zmarł prawicowy prezydent Chorwacji Franjo Tuđman, jednocześnie doszło do zmiany rządzącej koalicji. Zarówno zakończenie wojny, jak i zmiana nastrojów politycznych wpłynęły na osłabienie retradycjonalizowanych porządków dyskursu.

W konsekwencji w pierwszej dekadzie XXI wieku większą rolę zaczynają odgrywać modernizacyjne porządki dyskursu. W porządkach tych bardzo wyraźne jest utożsamienie Europy z Unią Europejską, zaś Unii Europejskiej z nowoczesnością i pozytywnie nacechowanymi wartościami kulturowymi?

Choć w 2008 r. wybuchł światowy kryzys finansowy, który dotknął także Chorwację, to badania socjologiczne wskazują, że pozycję modernizacyjnych porządków dyskursu osłabiło to tylko nieznacznie ${ }^{10}$. Niezależnie od kryzysu dłużniczego licznych państw południowoeuropejskich (m.in. Grecji, Hiszpanii, Portugalii), w 2013 r. Chorwacja przystąpiła do Unii Europejskiej.

Począwszy od 2015 r., kryzys migracyjny zaczyna być odnotowywany przez media i opinię publiczną. Powstaje więc pytanie, jak wpłynął on na dyskursy medialne w Chorwacji. Czy nasiliły się, podobnie jak w wielu innych państwach wschodnioeuropejskich, ksenofobiczne porządki dyskursu? Jeżeli tak - w jakim stopniu? Czy spowodowało to także poszerzenie reprezentacji porządków retradycjonalizowanych $\mathrm{w}$ dyskursie mediów?

Niniejszy artykul jest próbą odpowiedzi na powyższe pytania. Będzie on również śledził wpływ innych wydarzeń politycznych na dyskursywną reprezentację Europy w badanym korpusie, zaś rezultaty dociekań zostaną przedstawione na przykładzie lat 2014, 2015 i 2016.

\section{METODA I KORPUS}

W niniejszym artykule analizowany korpus stanowiły teksty z internetowego wydania chorwackiego dziennika „Večernji list” od października 2012 do października

$8 \quad$ W przypadku Chorwacji traktat regulował status Wschodniej Slawonii.

9 W wielu wypadkach tego rodzaju europeizacyjne porządki dyskursów modernizatorskich integrowały pewne znaki czy strategie argumentacyjne, których genezy można by się dopatrywać raczej w porządkach „przedmurza” czy np. skrajnych odmianach dyskursów XIX-wiecznej Partii Prawa. Mowa tu przede wszystkim o stosowaniu opozycji Europa-Batkany przy negatywnym nacechowaniu symbolu Bałkanów. Zob. np. N. Zambelli, Izmedu Balkana i Zapada: problem hrvatskog identiteta nakon Tudmana i diskurzivna rekonstrukcija regije, „Politička misao” 2010, nr 1(47), s. 55-76.

10 Nie ma badań poświęconych skutkom kryzysu obserwowalnym w porządkach dyskursu europejskiego. O niewielkim wpływie kryzysu na kształt tego porządku można wnioskować, np. obserwując socjologiczne badania postaw młodych w stosunku do integracji europejskiej - także w okresie kryzysu finansowego chorwacka opinia publiczna pozostawała nastawiona pozytywnie do wejścia Chorwacji w struktury Unii Europejskiej (zob. V. Ilišin, D. Bouillet, A. Gvozdanović, D. Potočnik, Mladi u vremenu krize, Zagreb 2013, s. 126-134; N. Blanuša, Euroskepticizam u Hrvatskoj, [w:] Hrvatska i Europa. Strahovi i nade, red. I. Šiber, Zagreb 2010, s. 11-46). 
2017 r. $^{11}$ Metodologię badań stanowiło połączenie narzędzi językoznawstwa korpusowego z podejściem analizy dyskursu.

$\mathrm{Z}$ jednej zatem strony zastosowano orientację na badania dużych zbiorów danych językowych - korpusów ${ }^{12}$.Z drugiej strony już samo podejście korpusowe nie ogranicza się do ilościowego podejścia do analizy lingwistycznej. Różnorodne konteksty - także pozajęzykoznawcze - i źródła danych są triangulowane w celu uzyskania możliwie bogatych interpretacji wyników ${ }^{13}$.

Natomiast dla analizy dyskursu podstawowe jest założenie, zgodnie z którym dyskursy są praktykami społecznymi zapośredniczającymi ideologie. Hybrydyczne metodologie nazywane korpusowo wspomaganymi badaniami dyskursu (ang. corpus-assisted discourse studies, CADS) ${ }^{14}$ - które stanowią istotną inspirację dla metod stosowanych w niniejszym artykule - wykorzystują korpusy tekstów do weryfikacji hipotez czy porównywania wniosków wyciągniętych z analizy jakościowej danej odmiany języka w odniesieniu do obserwacji ilościowej w korpusie referencyjnym lub innych stosownych korpusach specjalistycznych ${ }^{15}$.

W przypadku badań nad chorwackimi porządkami dyskursu europejskiego szczególnie istotne było nakreślenie wyczerpującej genealogii porządków, które potencjalnie mogą być reaktualizowane w analizowanym korpusie. Historycznie wykształcone porządki dyskursu oraz ich topika są następnie odnoszone do rezultatów analizy ilościowej w celu tak identyfikacji powtórzeń, jak i stwierdzenia innowacji.

W niniejszym artykule istotnym pojęciem należącym do metodologicznego repertuaru językoznawstwa korpusowego była kolokacja. Teoretycznym podłożem kolokacji jako narzędzia badawczego jest założenie, zgodnie z którym ważne aspekty znaczenia słowa

11 Dziennik „Večernji list” został wybrany do analizy w pierwszej kolejności z uwagi na to, że przez długi czas stanowił gazetę o najwyższym nakładzie spośród wydawnictw typu broadsheet (jakkolwiek wobec powszechności zjawiska tabloidyzacji mediów pojęcie jest to nieco rozmyte). Nakład dziennika wynosił 52627 egzemplarzy w 2013 r. Zob. D. Vozab, Tisak u krizi: analiza trendova u Hrvatskoj od 2008. do 2013, „Medijske studije” 2014, nr 5(10), s. 139-147. Wyższy nakład odnotowywała tylko gazeta „24 sata”, która według większości źródeł określana jest jako tabloid (por. dane bazy danych Eurotopics prowadzonej przez Bundeszentrale für Politische Bildung: 24 sata, [online] https:// www.eurotopics.net/en/148399/24-sata, 21.08.2018. Profil ideologiczny analizowanego dziennika "Večernji list” jest zasadniczo konserwatywny: its commentaries now provide space for political views that range from liberal-conservative to protofascist. Vecernji list is closely aligned with the national conservative HDZ party (por. dane Eurotopics: Večernji list, [online] https://www.eurotopics.net/en/148851/ veernji-list, 21.08.2018).

12 P. Baker, Using Corpora to Analyze Gender, London 2014, s. 7; T. McEnery, A. Hardie, Corpus Linguistics: Method, Theory and Practice, Cambridge 2012, s. 1, cyt. za: C. Hardaker, M. McGlashan, "Real Men Don't Hate Women". Twitter Rape Threats and Group Identity, "Journal of Pragmatics" 2016, nr 91 .

13 P. Baker i in., A Useful Methodological Synergy? Combining Critical Discourse Analysis and Corpus Linguistics to Examine Discourses of Refugees and Asylum Seekers in the UK Press, „Discourse and Society" 2008, vol. 19, nr 3, s. 273-306.

14 C. Hardaker, M. McGlashan, "Real Men...", s. 86.

15 P. Baker, Using Corpora in Discourse Analysis, London 2006, s. 15-17, cyt. za: C. Hardaker, M. McGlashan, "Real Men...". 
nie zawierają się tylko w wyizolowanej jednostce językowej. Wręcz przeciwnie: znaczenie ustanawiane jest w typowych związkach językowych, w które wchodzi dane słowo ${ }^{16}$. Stąd też kolokacje definiuje się jako dwa lub więcej stowa, które często używane są tacznie ${ }^{17}$.

Innym narzędziem, które zostało wykorzystane, były k-kolokacje (ang. consistent collocates, stałe kolokacje). Pojęcie to zostało zaczerpnięte z badań nad reprezentacją migrantów i migrantek w prasie brytyjskiej w projekcie RASIM ${ }^{18}$. Rozumiane jest jako stałe kolokacje występujące $\mathrm{w}$ większości podkorpusów danego korpusu (w tym wypadku: lat). Badanie k-kolokacji umożliwia rekonstrukcję trwałych aspektów analizowanego zjawiska przez eliminację kolokacji przygodnych, pojawiających się np. tylko w jednym roku. Co do aspektów technicznych, kolokacje analizowanych leksemów ustalane były przy użyciu programu komputerowego AntConc ${ }^{19}$, natomiast c-collocates znajdowano przy użyciu autorskich skryptów w języku programowania Python. Dodatkowo korpus poddany analizie uzyskano przez ograniczenie liczby próbek (downsampling) do około 10-12 tysięcy artykułów z każdego roku. Możliwe było to dzięki ograniczeniu bazy artykułów wyłącznie do tych, które zawierały ciąg znaków -europ- ${ }^{20}$.

\section{STAŁE KOLOKACJE}

Badanie stałych kolokacji, zwanych dalej k-kolokacjami, miało na celu ustalenie trwałego obrazowania Europy w analizowanym korpusie prasy. Pozwoliło jednocześnie na eliminację kolokacji przygodnych. K-kolokacje dla pojęcia Europy w badanym korpusie zostały podzielone według toposów, czyli stałych miejsc, wspólnych motywów, definiowanych za tradycjami semantyki historycznej w sposób następujący:

[...] unter 'Topoi' [sind] sowobl die allgemeinen Formprinzipien möglicher Argumente zu verstehen wie die zu Motiven, Denkformen, Themen, Argumenten, Klischees, loci communes, Stereotypen usw. stabilisierten Gehalte, wie sie unter Titeln wie 'bistorische, 'soziale', 'analytische Topik' untersucht werden ${ }^{21}$.

16 T. McEnery, A. Hardie, Corpus Linguistics..., s. 123, cyt. za: C. Hardaker, M. McGlashan, “Real Men...”.

17 P. Cantos Gómez, Statistical Methods in Language and Linguistic Research, Sheffield 2012, s. 196, cyt. za: C. Hardaker, M. McGlashan, "Real men...”.

18 P. Baker i in., A Useful Methodological Synergy?..., s. 286.

19 L. Anthony, AntConc 3.2.4 [program komputerowy], Tokyo 2014, [online] http://www.lauren ceanthony.net/, 21.08.2018.

20 Evropa i evropski tradycyjnie stanowily alternatywną postać chorwackiego wyrazu oznaczającego 'Europę. W słownikach występują jako rzadsze odpowiedniki preferowanej formy Europa, europski, jednak bez żadnej adnotacji. Można powiedzieć, że jeszcze w latach 90. formy Evropa, evropski nie były nacechowane ideologicznie, skoro były stosowane również przez polityków utożsamiających się z prawicą czy chorwackim nacjonalizmem. Obecnie prawdopodobnie coraz częściej postrzegane bywają jako niepożądany serbizm w chorwackim standardzie językowym, o czym może świadczyć to, że w badanym korpusie występują wyłącznie w cytatach z polityków serbskich i bośniackich.

21 J. Kopperschmidt, Formale Topik. Anmerkungen zu ihrer heuristischen Funktionalisierung innerhalb einer Argumentationsanalytik, [w:] Topik und Rhetorik. Ein interdisziplinäres Symposium, red. G. Ueding, Tübingen 1991, s. 53, cyt. za: M. Wengeler, Historische Diskurssemantik als Analyse 
„przez «toposy» [należy] rozumieć tak ogólne zasady formalne możliwych argumentów, jak i treści, które ustabilizowaty się w postaci motywów, form myślenia, tematów, argumentów, klisz, loci communes, stereotypów itp., a sq badane pod pojęciami takimi jak «topika historyczna», «spoteczna», «analityczna»".

Skoro więc toposy mogą być uobecniane przez np. loci communes czy klisze (językowe), to tego rodzaju użycia językowe można obserwować również w relewantnych kolokacjach danego leksemu. Jednocześnie topika zawarta w kolokacjach odsyła do bardziej złożonych strategii argumentacyjnych czy narracyjnych - a w ostatecznym rozrachunku do historycznie kształtowanych porządków dyskursu.

Analiza najczęstszych kolokacji leksemu Europa we wszystkich badanych subkorpusach pozwoliła na zaobserwowanie pewnych powtarzających się kategorii toposów. Aby móc obserwować zmiany najczęstszej topiki w dyskursach europejskich, zaproponowano następującą klasyfikację najczęstszych toposów-kolokacji.

- Przeważającą liczbę toposów stanowiły te nawiązujące do GEOGRAFII, np. gradovi - 'miasta', dio - 'część, srce - 'serce', jugoistoćna - 'południowowschodnia', istok - 'wschód', bliski - 'bliski'.

- Występowały także toposy odwołujące się do INSTYTUCJI (POLITYCZNYCH I SPOŁECZNYCH), np. vijeće - 'rada', ujedinjen - 'zjednoczony', država - 'państwo';

- do POLITYKI, np. budućnost - 'przyszłość', kriza - 'kryzys';

- do GOSPODARKI, np. triziziste - 'rynek'.

- Pewną część toposów stanowiły kolokacje nierelewantne lub na tyle wieloznaczne, że nie można było rozstrzygnąć co do ich przynależności kategorialnej; za nierelewantne dla przeprowadzanej analizy uznano też bardzo liczne kolokacje nawiązujące do SPORTU oraz KULTURY, przede wszystkim popularnej ${ }^{22}$.

Mając na uwadze cel badań - a zatem kontekstowo uwarunkowaną ewolucję językowego modelowania pojęcia Europy - w ramach k-kolokacji z domeny GEOGRAFII wyznaczone zostały następujące „sub-toposy”:

- toposy wyznaczające relację EUROPA-CHORWACJA, które językowo sytuują Chorwację w ramach wyobrażonej geografii Europy, np. središnji - "środkowy',jugoistočni - 'południowowschodni';

- wyznaczające relację EUROPA-ŚWIAT, a więc odnoszące pojęcie Europy do wyobrażonej geografii całego świata, np. izvan - 'poza', bliski - 'bliski', Afrika - 'Afryka', Amerika - 'Ameryka'; są to zatem kolokacje, które mogą stawać się częściami większych toposów, modelujących wyobrażeniową relację Europy z Innymi;

von Argumentationstopoi, [w:] Linguistische Diskursanalyse. Neue Perspektiven, red. D. Busse, W. Teubert, Wiesbaden 2013, s. 189-215.

22 Przykładowo, za nierelewantne uznawano kolokacje, w których leksem Europa wchodził w skład nazw własnych (festiwali czy firm) innych niż geograficzne. Badania tego typu kolokacji mogłyby oczywiście dostarczyć cennej wiedzy o dodatkowych konotacjach znaku EUROPA, jednak nie dostarczają informacji dotyczących kulturowej i geograficznej delimitacji granic. Podobnie rzecz się ma z kolokacjami pochodzącymi z domeny SPORTU. 
- pozostate METAFORY PRZYNALEŻNOŚCI, np. karta - 'mapa', pripada - 'należy';

- toposy służące WEWNĘTRZNEJ ORIENTACJI, które sytuują językowo na wyobrażonej mapie Europy inne jej państwa, np. srce - 'serce', sjeverni - 'północny';

- pozostałe, np. nalaziti - 'znajdować (się)', dio - 'część.

Stworzenie tego rodzaju klasyfikacji umożliwiło następnie scharakteryzowanie czasowej zmienności dyskursu europejskiego w prasie chorwackiej w odniesieniu do trwałych cech obrazu Europy. Niniejszy artykuł prezentuje zmianę w językowym modelowaniu granic Europy w ramach chorwackich porządków dyskursu na przykładzie lat 2014, 2015 i 2016. Kolokacje typowe dla poszczególnych subkorpusów wraz z ich przynależnością do kategorii $\mathrm{w}$ ramach klasyfikacji toposów zostały przedstawione w Tabeli 1.

W dalszym ciągu artykułu owa zmienność czasowa zostanie scharakteryzowana: przywołany zostanie szerszy kontekst pozajęzykowy (polityczny i społeczny) oraz kontekst językowy najbardziej charakterystycznych wystąpień kolokacji leksemu Europa w ramach poszczególnych analizowanych subkorpusów.

\section{KOLOKACJE EUROPY W WYBRANYCH SUBKORPUSACH}

2014

W 2014 r. w artykułach traktujących o Europie dominuje topika polityczna, to znaczy taka, której argumentacja opiera się na ocenie i propozycjach działań politycznych. Zdarzają się reprezentacje zjawisk politycznych czy społecznych określane jako zagrożenia (prijetnje). Uwagę zwraca jednak, że w ogromnej większości wypadków po leksemie zagrożenie następuje dookreślenie, np. zagrożenia zależnością od rosyjskiego gazu (Europi prijeti ovisnost o ruskom plinu), niemiecka zależność od rosyjskiego gazu zagraża Europie (Njemačka ovisnost o ruskom plinu prijeti Europi). Może to świadczyć o próbie racjonalizacji tego rodzaju zagrożeń, o ich reprezentacji przy użyciu strategii argumentacyjnych odwołujących się do innych instancji niż tylko nieokreślone poczucie strachu.

Leksem integracija pojawia się praktycznie wyłącznie w kontekście instytucjonalnej integracji państw w system Unii Europejskiej, np.:

U glavnom gradu Ukrajine, Kijevu, oko 100.000 ljudi pjevalo je himnu na gradskom Trgu nezavisnosti u prilog daljnjoj integraciji u Europu ${ }^{23}$.

'W stolicy Ukrainy Kijowie około 100000 osób odśpiewało hymn na Majdanie Niepodległości jako symbol poparcia dla dalszej integracji z Europą.

23 Wszystkie cytaty w artykule - jeżeli nie zaznaczono inaczej - pochodzą z korpusu artykułów z internetowego wydania dziennika „Večernji list” opublikowanych od października 2012 do października 2017 r. Szczegóły przygotowania korpusu opisane są we wstępie artykułu. Tłumaczenia terminów chorwackich pochodzą od autora. 


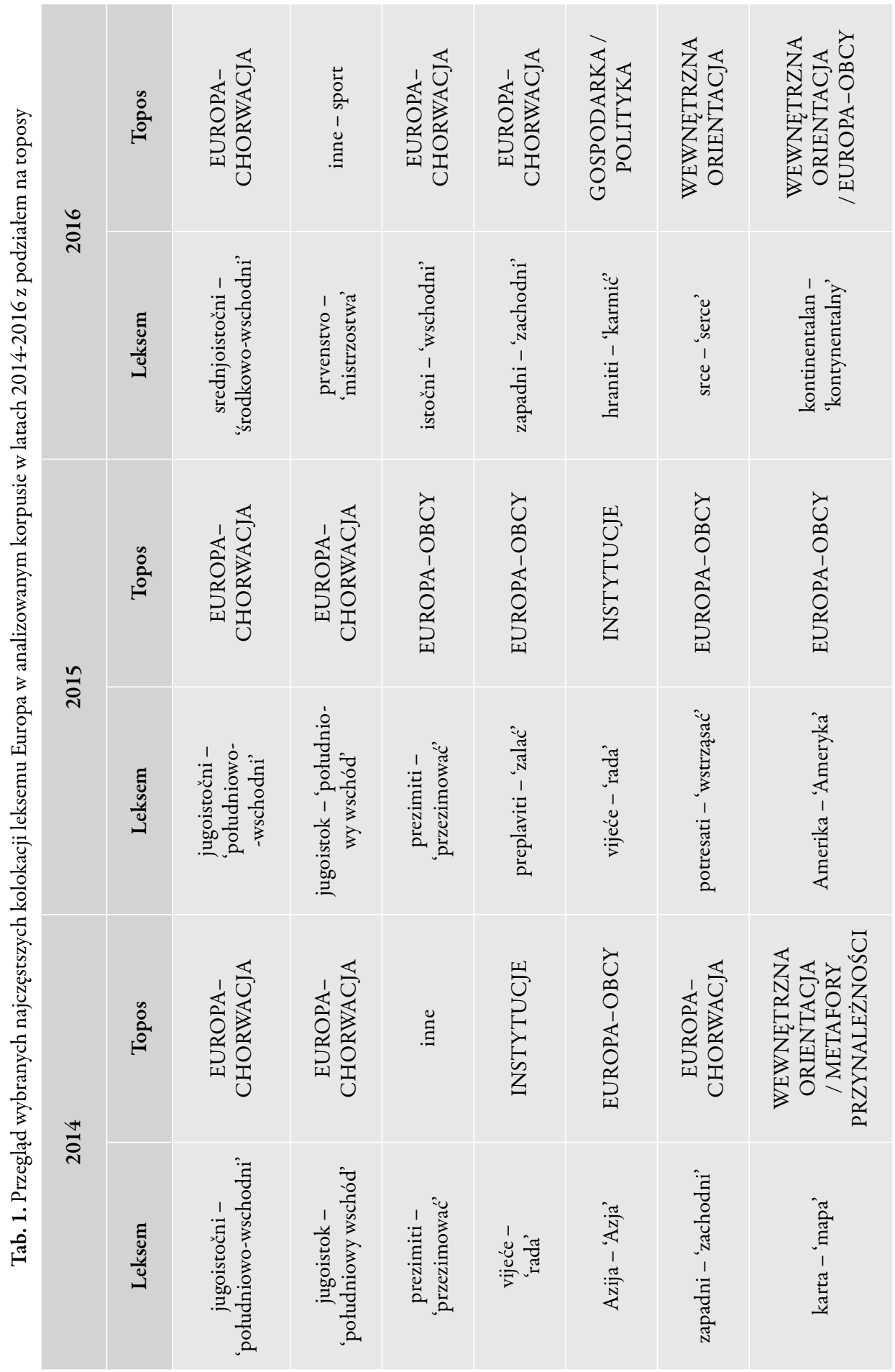




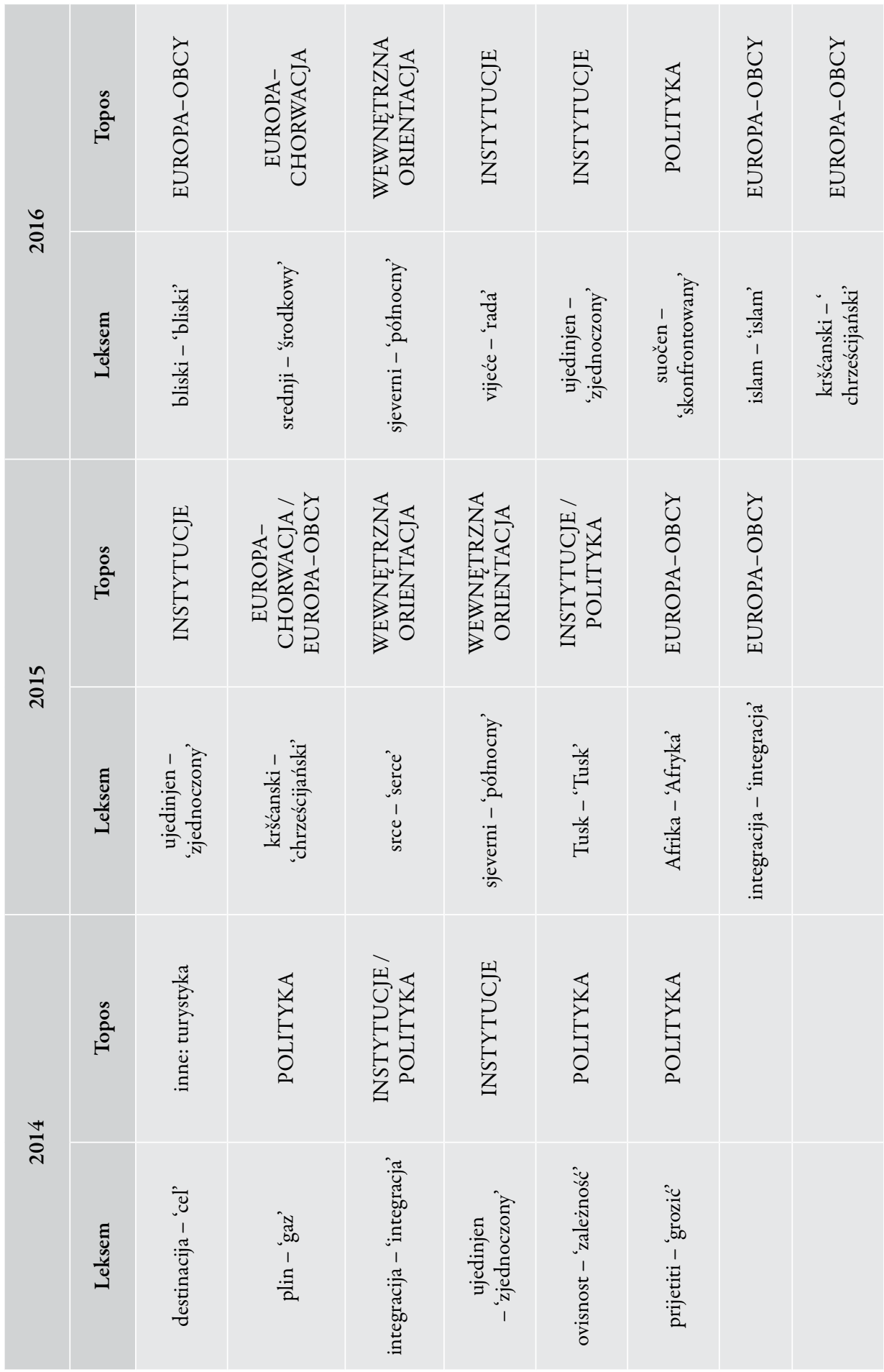


Tabela 2. Wybrane częste kolokacje leksemu Europa w artykułach dziennika „Večernji list” z 2014 r. $\mathrm{R}=$ ranga, $\mathrm{F}=$ częstotliwość, $\mathrm{IW}$ = współczynnik informacji wzajemnej, ang. mutual information, MI. Nie uwzględniono kolokacji nierelewantnych, a także uwzględnionych na wyżej rangowanych miejscach form fleksyjnych

\begin{tabular}{|c|c|c|c|c|c|}
\hline Leksem & $\mathbf{R}$ & $\mathbf{F}$ & IW & Topos & Znaczenie \\
\hline jugoistočni & 1 & 278 & 10,83222 & EUROPA-CHORWACJA & $\begin{array}{l}\text { 'południowo- } \\
\text {-wschodni' }\end{array}$ \\
\hline jugoistok & 2 & 22 & 10,75304 & EUROPA-CHORWACJA & $\begin{array}{l}\text { 'południowy } \\
\text { wschód' }\end{array}$ \\
\hline prezimiti & 4 & 29 & 10,29744 & inne & 'przezimować' \\
\hline vijeće & 7 & 14 & 9,71394 & INSTYTUCJE & 'rada' \\
\hline Azija & 18 & 19 & 8,70282 & EUROPA-OBCY & 'Azja' \\
\hline zapadni & 21 & 141 & 8,38541 & EUROPA-CHORWACJA & 'zachodni' \\
\hline karta & 24 & 15 & 8,01830 & $\begin{array}{l}\text { WEWNĘTRZNA ORIENTACJA / } \\
\text { METAFORY PRZYNALEŻNOŚCI }\end{array}$ & 'mapa' \\
\hline destinacija & 26 & 21 & 7,92693 & inne: turystyka & 'cel' \\
\hline plin & 31 & 10 & 7,65776 & POLITYKA & 'gaz' \\
\hline integracija & 40 & 25 & 7,44315 & INSTYTUCJE / POLITYKA & 'integracja' \\
\hline ujedinjen & 46 & 19 & 7,03252 & INSTYTUCJE & 'zjednoczony' \\
\hline ovisnost & 55 & 9 & 6,69637 & POLITYKA & 'zależność' \\
\hline prijetiti & 75 & 13 & 5,77861 & POLITYKA & 'grozić' \\
\hline
\end{tabular}

W kolokacjach zawierających leksem Europa nie pojawiają się zatem inne możliwe znaczenia polisemicznego wyrazu integracija. Prymarną konotacją frazy integracja europejska w chorwackim dyskursie medialnym pozostaje proces poszerzania i uspójniania struktur Unii Europejskiej. Integracja ta jest zasadniczo przedstawiana jako zjawisko pozytywne i pożądane, nawet jeśli potencjalnie może rodzić trudności. 


\section{5}

Tabela 3. Wybrane częste kolokacje leksemu Europa w artykułach dziennika „Večernji list” z 2015 r.

$\mathrm{R}=$ ranga, $\mathrm{F}=$ częstotliwość, $\mathrm{IW}=$ współczynnik informacji wzajemnej, ang. mutual information, MI. Nie uwzględniono kolokacji nierelewantnych, a także uwzględnionych na wyżej rangowanych miejscach form fleksyjnych

\begin{tabular}{|c|c|c|c|c|c|}
\hline Leksem & $\mathbf{R}$ & F & IW & Topos & Znaczenie \\
\hline jugoistočan & 3 & 295 & 10,6769 & EUROPA-CHORWACJA & $\begin{array}{l}\text { 'południowo- } \\
\text {-wschodni' }\end{array}$ \\
\hline jugosistok & 5 & 30 & 9,96259 & EUROPA-CHORWACJA & $\begin{array}{l}\text { 'południowy } \\
\text { wschód' }\end{array}$ \\
\hline prezimiti & 10 & 10 & 9,30101 & EUROPA-OBCY & 'przezimować' \\
\hline preplaviti & 14 & 15 & 8,63543 & EUROPA-OBCY & 'zalać' \\
\hline vijeće & 17 & 66 & 8,37763 & INSTYTUCJE & 'rada' \\
\hline potresati & 21 & 9 & 8,05279 & EUROPA-OBCY & 'wstrząsać' \\
\hline Amerika & 24 & 15 & 7,89846 & EUROPA-OBCY & 'Ameryka' \\
\hline ujedinjen & 32 & 27 & 7,38738 & INSTYTUCJE & 'zjednoczony' \\
\hline kršćanski & 33 & 26 & 7,32805 & $\begin{array}{c}\text { EUROPA-CHORWACJA } \\
\text { / EUROPA-OBCY }\end{array}$ & 'chrześcijański' \\
\hline srce & 34 & 11 & 7,29649 & WEWNĘTRZNA ORIENTACJA & 'serce' \\
\hline sjeverni & 35 & 38 & 7,19625 & WEWNĘTRZNA ORIENTACJA & 'północny' \\
\hline Tusk & 37 & 12 & 7,14590 & INSTYTUCJE / POLITYKA & 'Tusk' \\
\hline Afrika & 39 & 18 & 7,11824 & EUROPA-OBCY & 'Afryka' \\
\hline integracija & 60 & 17 & 6,14974 & EUROPA-OBCY & 'integracja' \\
\hline
\end{tabular}

W 2015 r. dochodzi do zasadniczej zmiany w dominujących trendach w dyskursie analizowanej prasy. Wydarzenia polityczne dotyczące Europy komentowane są dużo częściej przy użyciu topiki tożsamościowej, tzn. definiującej przynależność aktorów społecznych w kategoriach swój-obcy. Silnie zmetaforyzowane ujęcia procesów politycznych czy społecznych stają się powszechniejsze, np. kolokacje leksemu Europa 
z czasownikami preplaviti - 'zalać' czy też potresati - 'wstrząsać' odnoszą się do toposów zalewania Europy przez uchodźców (preplave Europu) czy kryzysu uchodźczego, który nia wstrzasa (izbjeglička kriza koja potresa Europu), np.:

Ako se to ne dogodi, Europu će preplaviti milijuni izbjeglica, a nijedna zemlja neće biti sigurna od terorista, rekao je Putin.

'Jeśli się to nie stanie, Europę zaleją miliony uchodźców, a żaden kraj nie będzie bezpieczny od terrorystów - powiedział Putin'.

Europska komisija danas je objavila nekoliko prioritetnih poteza koje namjerava napraviti tijekom sljedećih šest mjeseci u povodu izbjegličke krize koja potresa Europu.

'Komisja Europejska dziś ogłosiła kilka priorytetowych ruchów, które zamierza wykonać w ciągu najbliższych sześciu miesięcy w związku z kryzysem uchodźczym, który wstrząsa Europa.

Językowe modelowanie migracji w domenie klęski żywiołowej - a nawet konkretne językowe przedstawienie LUDZIE JAKO CIECZ (stąd obraz powodzi) - zostało zresztą zaobserwowane wcześniej w niektórych innych dyskursach medialnych, np. w dyskursie brytyjskich tabloidów ${ }^{24}$. Metaforyka ta charakteryzuje się przedstawianiem zjawisk społecznych, w których biorą udział zróżnicowane jednostki ludzkie, jako fenomenów zupełnie niezależnych od ingerencji np. politycznej czy ekonomicznej. Cechą klęski żywiołowej - a więc powodzi czy trzęsienia ziemi - jest jej nieuchronność, a przynajmniej niemożliwość kontroli i wpływania na jej przyczyny. Metody radzenia sobie z klęskami elementarnymi to łagodzenie skutków lub przeciwdziałanie. Przede wszystkim zaś tego typu kataklizmy uważane są za wydarzenia jednoznacznie groźne i szkodliwe, takie, którym należy przeciwdziałać, np. budując tamy. Zastosowanie tego typu topiki w odniesieniu do domeny jednostek ludzkich w sposób oczywisty narzuca pewne ramy dyskursu, w obrębie których następnie budowana jest argumentacja.

W subkorpusie dla 2015 r. dużo częściej pojawia się kolokacja chrześcijańska Europa (kršćanska Europa), definiująca wspólnotę społeczno-polityczną w kategoriach - prymordialnej w zasadzie - tożsamości religijnej, np.:

Koliko je migranata u potrazi za azilom u krš́anskoj Europi sudjelovalo u njihovu progonu, nećemo nikad otkriti u potpunosti, no znamo da se taj progon nastavlja i u izbjeglištvu. Muslimanski su migranti u travnju s broda u more i smrt bacili dvanaestero kršćana.

'Tego, ilu migrantów w poszukiwaniu azylu w chrześcijańskiej Europie brało udział w jej prześladowaniach, w zupełności nie dowiemy się nigdy, ale wiemy, że prześladowania te trwają także na uchodźstwie. Muzułmańscy migranci w kwietniu zrzucili z pokładu statku w morze dwunastu chrześcijan'.

Zarówno wewnętrzne zróżnicowanie, jak i inne możliwe cechy denotatywne i konotatywne pojęcia Europy ustępują tu tożsamości wyznaniowej. Główną strategią retoryczną, wykorzystywaną przez nadawców tego rodzaju dyskursu, jest językowe modelowanie Obcego w kategoriach my-oni. Jeżeli Europa jest definiowana w kategoriach religijnych i określona jako chrześcijańska, to Obcy będzie również charakteryzowany

24 P. Baker i in., A Useful Methodological Synergy?... 
wyznaniowo - w sposób uogólniony jako muzutmanin, a bez uwzględnienia zróżnicowania oraz innych cech denotatywnych i konotatywnych.

Należy zwrócić uwagę, że kolokacja ta jednak nierzadko pojawiała się też w kontekstach stanowiących kontrtopos wobec ksenofobicznej topiki katolickiej, a to przez odwołanie do humanitarnych aspektów etyki chrześcijańskiej (np. okrenuli madarskom premijeru Orbanu kao uzornom branitelju nacije i ćuvaru kršćanske Europe bodljikavom žicom, pendrecima, oružjem i psima - 'odwrócili się ku węgierskiemu premierowi Orbanowi jako wzorcowemu obrońcy narodu i stróżowi chrześcijańskiej Europy z pomocą drutu kolczastego, pałek policyjnych, broni i psów'). Mowa więc o stosunkowo częstym ironicznym użyciu toposu chrześcijańskiej Europy, krytycznym wobec postawy tych nadawców, którzy stosują ów topos nieironicznie.

W subkorpusie dla 2015 r. leksem integracija w większości swych wystąpień denotuje procesy włączania migrantów i migrantek do społeczeństw państw przyjmujących, np.:

Getoiziranje imigranata u zasebnim naseljima, kakvo postoji u zapadnim zemljama, nije integracija te šteti i Europi i imigrantima.

'Gettoizacja imigrantów w oddzielnych osiedlach, do jakiej dochodzi w państwach zachodnich, nie jest integracją i szkodzi tak Europie, jak imigrantom'.

Zwraca szczególną uwagę, że procesy integracji migrantów są zazwyczaj zresztą przedstawiane w negatywnym świetle. Kiedy leksemy Europa i integracija kolokują ze sobą $\mathrm{w}$ analizowanym dyskursie medialnym, szczegółowe aspekty integracji migrantów ze społeczeństwami przyjmującymi nie są komentowane szczególnie szeroko. Badane dyskursy zadowalają się raczej powierzchownymi, powtarzającymi się wyjaśnieniami, takimi jak podana w przykładzie gettoizacja; teksty, które np. wyjaśniałyby uwarunkowania tego typu zjawisk, nie występują.

Spada natomiast częstość występowania leksemu integracija w znaczeniu procesów włączania w struktury Unii Europejskiej. Można to zapewne tłumaczyć dłuższym czasem, który upłynął od przyjęcia Chorwacji do UE.

\section{6}

Tabela 4. Wybrane częste kolokacje leksemu Europa w artykułach dziennika „Večernji list” z 2016 r. $\mathrm{R}=$ ranga, $\mathrm{F}=$ częstotliwość, $\mathrm{IW}=$ współczynnik informacji wzajemnej, ang. mutual information, $M I$. Nie uwzględniono kolokacji nierelewantnych, a także uwzględnionych na wyżej rangowanych miejscach form fleksyjnych

\begin{tabular}{|c|c|c|c|c|c|}
\hline Leksem & R & F & IW & Topos & Znaczenie \\
\hline srednjoistočni & 2 & 15 & 12,39210 & EUROPA-CHORWACJA & $\begin{array}{c}\text { 'środkowo- } \\
\text {-wschodni' }\end{array}$ \\
\hline prvenstvo & 9 & 13 & 11,43076 & inne-sport & 'mistrzostwa' \\
\hline istočni & 10 & 330 & 11,37377 & EUROPA-CHORWACJA & 'wschodni' \\
\hline
\end{tabular}




\begin{tabular}{|c|c|c|c|c|c|}
\hline Leksem & $\mathbf{R}$ & $\mathrm{F}$ & IW & Topos & Znaczenie \\
\hline zapadni & 17 & 213 & 10,29362 & EUROPA-CHORWACJA & 'zachodni' \\
\hline hraniti & 18 & 10 & 10,22217 & GOSPODARKA / POLITYKA & 'karmić' \\
\hline srce & 23 & 21 & 9,83313 & WEWNĘTRZNA ORIENTACJA & 'serce' \\
\hline kontinentalni & 25 & 14 & 9,63435 & $\begin{array}{c}\text { WEWNĘTRZNA ORIENTACJA / } \\
\text { EUROPA-OBCY }\end{array}$ & 'kontynentalny' \\
\hline bliski & 29 & 11 & 9,35968 & EUROPA-OBCY & 'bliski' \\
\hline srednji & 31 & 121 & 9,30999 & EUROPA-CHORWACJA & 'środkowy' \\
\hline sjeverni & 37 & 62 & 9,03852 & WEWNĘTRZNA ORIENTACJA & 'północny' \\
\hline vijeće & 41 & 19 & 8,78477 & INSTYTUCJE & 'rada' \\
\hline ujedinjen & 46 & 37 & 8,61251 & INSTYTUCJE & 'zjednoczony' \\
\hline suočen & 50 & 12 & 8,49274 & POLITYKA & $\begin{array}{l}\text { 'skonfronto- } \\
\text { wany' }\end{array}$ \\
\hline islam & 55 & 24 & 8,24045 & EUROPA-OBCY & ‘islam’ \\
\hline kršćanski & 60 & 12 & 7,97741 & EUROPA-OBCY & 'chrześcijański' \\
\hline
\end{tabular}

W subkorpusie artykułów z 2016 r. kontynuowane są trendy zaobserwowane już w topice z 2015 r. Istotną rolę odgrywają więc wciąż toposy tożsamościowe, ujmujące wydarzenia polityczne w kategoriach swój-obcy. Obok tego występują kolokacje leksemu Europa, które służą umiejscawianiu Chorwacji w ramach szerszej wspólnoty europejskiej.

Co do toposów związanych z ustanawianiem tożsamości europejskiej, to nowym zjawiskiem są wypowiedzi dotyczące kontynentalnej Europy. Jest to związane z Brexitem i koniecznością językowego modelowania pozostałej części Unii Europejskiej, z wyłączeniem Wielkiej Brytanii, opuszczającej UE:

Kontinentalna Europa ne gubi mnogo na Brexitu osim što će joj nedostajati jak britanski potrošač koji je uz pomoć stabilnosti funte uvijek bio malo boljeg standarda od ostalih stanovnika EU.

'Kontynentalna Europa nie traci wiele na Brexicie, oprócz tego że będzie jej brakować silnych brytyjskich konsumentów, którzy z pomocą stabilności funta zawsze cieszyli się nieco lepszym standardem od pozostałych mieszkańców UE'.

Uwagę zwraca wielość znaczeń, polisemiczność leksemu Europa w chorwackich dyskursach europejskich. Wyraz ten denotuje bowiem nie tylko wspólnotę 
terytorialno-kulturalną, ale także głęboko z nią synonimizowaną sieć instytucji, przede wszystkim zaś - Unię Europejską (a także różnego rodzaju imprezy i instytucje sportowe).

Wyraz bliski występuje głównie w kolokacji Bliski Wschód (chorw. Bliski Istok); o regionie tym mówi się praktycznie wyłącznie w kontekście konfliktów militarnych i terroryzmu.

Europa zaś jest bardzo często przedstawiana jako dotknięta kryzysami, z którymi musi się konfrontować (chorw. suočavati):

Pobjeda Norberta Hofera iz Slobodarske stranke (FPÖ) osnažila bi protumigracijski i euroskeptični populistički pokret u Europi suočenoj s izbjegličkom krizom i to pred skorašnji referendum na kojem Britanci odlučuju o izlasku ili ostanku u Europskoj uniji.

'Zwycięstwo Norberta Hofera z Austriackiej Partii Wolności (FPÖ) umocniłoby tendencje antymigracyjne i eurosceptyczne w Europie skonfrontowanej z kryzysem uchodźczym tuż przed zbliżającym się referendum, na którym Brytyjczycy zdecydują o wyjściu lub pozostaniu w Unii Europejskiej'.

Zauważalne jest, że leksem ten najczęściej występuje w kontekście kwestii migracji, która w badanym subkorpusie modelowana jest jako najpoważniejszy problem Europy. Modelowanie przy użyciu leksemu suočavati se - 'konfrontować się wprowadza metaforykę konfliktu, w prymarnym, dosłownym znaczeniu słowa konfrontować można się z wrogiem. W odniesieniu do migracji tego typu dyskursy jednoznacznie modelują zjawisko to jako niechciane, kłopotliwe.

Widoczne jest też, że strategie argumentacyjne w analizowanych fragmentach korpusu świadczą o rozumieniu kryzysu migracyjnego jako problemu bardzo złożonego czy wręcz pozbawionego rozwiązania - dowodzi o tym użycie czasownika suočavati se w formie imiesłowowego atrybutu leksemu Europa. W takiej ramie dyskursywnej bycie skonfrontowanym z kwestią migracji jest stałą cechą Europy. Wreszcie na marginesie należy znów zauważyć silne utożsamienie Europy z Unią Europejską.

Stosunkowo często zaczyna pojawiać się definiowanie przynależności czy też stosunku wobec obcych na podstawie kryterium religijnego. Przejawia się to w częstotliwości kolokacji leksemu Europa z wyrazami islam czy też chrześcijańska (chorw. kršćanska; przede wszystkim w cytatach i kryptocytatach), np.:

Dvodnevni politički teatar, koji smo gotovo neprekinuto mogli pratiti na javnoj televiziji, imao je dvostruki zadatak: impresionirati brojnu tursku političko-gospodarsku delegaciju i odaslati poruku o navodnom hrvatskom pronalasku recepta za rješavanje položaja islama u Europi.

'Dwudniowy teatr polityczny, który mogliśmy niemal nieprzerwanie śledzić w telewizji publicznej, miał podwójne zadanie: wywrzeć wrażenie na licznej tureckiej delegacji polityczno-ekonomicznej i szerzyć przesłanie o rzekomym znalezieniu przez Chorwację recepty na rozwiązanie sytuacji islamu w Europie’.

Desničarske stranke u Poljskoj, Mađarskoj, Slovačkoj itd. govore da žele obraniti kršćanske korijene Europe, da žele obraniti ono što je nacionalno.

'Partie prawicowe w Polsce, na Węgrzech, Słowacji itd. mówią, że chcą obronić chrześcijańskie korzenie Europy, że chcą obronić to, co narodowe’. 
Może to świadczyć o tym, że leksem Europa zaczyna być w coraz większym stopniu modelowany w dyskursie medialnym jako znak wspólnoty opartej na tożsamości, której składnikiem jest stosunek do religii - zarówno muzułmańskiej, jak i chrześcijańskiej. Należy zauważyć, że analizowany korpus przytacza rozmaite strategie argumentacyjne - przykładowo, podane poświadczenie frazy chrześcijańskie korzenie Europy (kršćanske korijene Europe) dystansuje się od tego obrazu językowego poprzez zastosowanie mowy zależnej. Jednocześnie jednak zaświadcza o istnieniu tego typu obrazowania i w konsekwencji w ramach dyskursu medialnego aktualizuje i uwidacznia topos definiujący Europę w relacji do Innego przy zastosowaniu odniesienia religijnego.

\section{PODSUMOWANIE}

Ogólnie biorąc, nie ma wątpliwości, że utożsamienie Europy z Uniq Europejska jest w prasie chorwackiej bardzo mocne. Stąd np. przed 2013 r. - a w pewnej mierze także nadal - siła metaforyki w rodzaju drogi do Europy (chorw.put u Europu) lub europejskiej rodziny (chorw. europska obitelj). Rodzi to także konsekwencje dla modelowania granic Europy. Na skutek tego Rosja bardzo często językowo stawiana jest poza granicami Europy (kiedy mowa o rosyjskim zagrożeniu dla Europy). Konsekwencją takiego obrazowania była także konieczność wprowadzenia sformułowania kontynentalna Europa po Brexicie i nieprototypowa, peryferyjna pozycja Wielkiej Brytanii w ramach językowego modelu Europy.

Zasadniczą zmianą w topice dyskursu europejskiego w chorwackiej prasie, która zaszła po 2015 r., jest jednak odejście od strategii argumentacyjnych opartych na topice prawnej, ekonomicznej czy nawet militarnej, którą można było obserwować jeszcze w 2014 r. w kontekście konfliktu ukraińsko-rosyjskiego (zależność od rosyjskiego gazu).

Począwszy od 2015 r., dominować zaczyna topika tożsamościowa (reprezentująca świat w kategoriach swój-obcy, nałożona na podziały religijne chrześcijaństwo-islam), połączona z metaforyką klęski żywiołowej. Stąd prasa mogła mówić o kryzysie migracyjnym wstrzasajacym Europą czy też o milionach uchodźców, którzy mieliby zalać Europę. Dyskurs ten przedstawia zróżnicowane grupy ludzi w ramach semantycznej domeny sił przyrody. Taka topika pozwala prasie obyć się bez jakichkolwiek innych strategii argumentacyjnych. Klęska żywiołowa jest bowiem zjawiskiem, na którego przyczyny nie można wpływać. Interwencja ludzka może bądź złagodzić jej skutki, bądź też w przyszłości jej zapobiec.

Metaforyka przenosząca zjawisko migracji w semantyczną domenę przyrody nie jest zjawiskiem wyłącznie chorwackim. Zaobserwowano ją już wcześniej w brytyjskich badaniach nad dyskursem tabloidów. Jednakże niniejsze badania umożliwiły dostrzeżenie momentu, w którym topika ta po raz pierwszy pojawiła się w ramach chorwackiego porządku dyskursu europejskiego - prawdopodobnie wskutek rosnącej internacjonalizacji dyskursów i tematów medialnych.

Wreszcie na końcu należałoby zaznaczyć, że niniejszy artykuł miał na celu zarysowanie wstępnych perspektyw badawczych nad dynamiką zjawisk w dyskursie medialnym, 
z których niektóre były dopiero w stadium zalążkowym. Niewątpliwie konieczne będzie monitorowanie podobnych fenomenów ilościowych w przyszłości, także na szerszym korpusie czasopism o zróżnicowanym profilu ideologicznym. Równie istotny jest jednak szczegółowy jakościowy wgląd w realizacje dyskursów, jak również analiza relacji pojęcia Europy z konceptami blisko powiązanymi.

\section{BIBLIOGRAFIA}

24 sata [raport z bazy danych Eurotopics prowadzonej przez Bundeszentrale für Politische Bildung], [online] https://www.eurotopics.net/en/148399/24-sata.

Anthony L., AntConc 3.2.4 [program komputerowy], Tokyo 2014, [online] http://www.laurenceanthony.net/.

Baker P., Using Corpora in Discourse Analysis, London 2006.

Baker P. i in., A Useful Methodological Synergy? Combining Critical Discourse Analysis and Corpus Linguistics to Examine Discourses of Refugees and Asylum Seekers in the UK Press, „Discourse and Society" 2008, vol. 19, nr 3.

Blanuša N., Euroskepticizam u Hrvatskoj, [w:] Hrvatska i Europa. Strahovi i nade, red. I. Šiber, Zagreb 2010.

Cantos Gómez P., Statistical Methods in Language and Linguistic Research, Sheffield 2012.

Czerwiński M., Europa jako znak w nowomowie jugostowiańskich komunistów na przyktadzie wystąień Josipa Broza Tity, „Slavia Meridionalis” 2012, nr 12.

Dąbrowska-Partyka M., Geografia wyobrażona. Mapy jugostowiańskie i postjugostowiańskie, [w:] Zrozumieć Stowiańszczyznę, red. M. Dąbrowska-Partyka, Kraków 2010.

Dijk T. van, Badania nad dyskursem, [w:] Dyskurs jako struktura i proces, red. T. van Dijk, przeł. G. Grochowski, Warszawa 2001.

Dyras M., Re-inkarnacje narodu. Chorwackie narracje tożsamościowe w latach dziewięćdziesiątych XX wieku, Kraków 2009.

Hardaker C., McGlashan M., "Real Men Don't Hate Women". Twitter Rape Threats and Group Identity, ,Journal of Pragmatics” 2016, nr 91.

Ilišin V., Bouillet D., Gvozdanović A., Potočnik D., Mladi u vremenu krize, Zagreb 2013.

Kopperschmidt J., Formale Topik. Anmerkungen zu ihrer heuristischen Funktionalisierung innerhalb einer Argumentationsanalytik, [w:] Topik und Rhetorik. Ein interdisziplinäres Symposium, red. G. Ueding, Tübingen 1991.

Lisowska-Magdziarz M., Analiza tekstu w dyskursie medialnym, Kraków 2009.

McEnery T., Hardie A., Corpus Linguistics: Method, Theory and Practice, Cambridge 2012.

Rapacka J., Leksykon tradycji chorwackich, Warszawa 1997.

Stehlík P., Predzide i most: simbolicka konceptualizacija graničnoga položaja Hrvatske u izvornome jugoslavizmu, [w:] Symbole wtadzy - wtadza symboli, red. M. Dyras, B. Suchoń-Chmiel, T. Kwoka, Kraków 2014.

Vecernji list [raport z bazy danych Eurotopics prowadzonej przez Bundeszentrale für Politische Bildung], [online] https://www.eurotopics.net/en/148851/veernji-list. 
Vozab D., Tisak u krizi: analiza trendova u Hrvatskoj od 2008. do 2013, „Medijke studije” 2014, $\operatorname{nr} 5(10)$.

Wengeler M., Historische Diskurssemantik als Analyse von Argumentationstopoi, [w:] Linguistische Diskursanalyse. Neue Perspektiven, red. D. Busse, W. Teubert, Wiesbaden 2013.

Zambelli N., Izmedu Balkana i Zapada: problem hrvatskog identiteta nakon Tudmana i diskurzivna rekonstrukcija regije, „Politička misao” 2010, nr 1 (47).

Piotr MIROCHA - doktorant w Instytucie Filologii Słowiańskiej Uniwersytetu Jagiellońskiego, absolwent Międzywydziałowych Indywidualnych Studiów Humanistycznych UJ (2016). Bada polityczne uwikłania użyć języka w kulturach południowosłowiańskich przy użyciu metodologii ilościowej i jakościowej analizy dyskursu oraz podejść semiotycznych. 